\title{
Growth and survival of Icelandic capelin Mallotus villosus larvae
}

\author{
Anna Heida Olafsdottir ${ }^{1, *}$, John T. Anderson ${ }^{2}$ \\ ${ }^{1}$ Ocean Sciences Centre, Memorial University of Newfoundland, St. John's, Newfoundland A1C 5S7, Canada \\ ${ }^{2}$ Northwest Atlantic Fisheries Centre, Fisheries and Oceans Canada, PO Box 5667, St. John's, Newfoundland A1C 5X1, Canada
}

\begin{abstract}
Otolith increment analysis was used to reconstruct daily growth of 2 year-classes of capelin larvae, from hatch until 4 mo of age. Larvae were sampled on the continental shelf around Iceland during August 2001 and 2002. Mean hatch dates were not different between years, but hatching started earlier and lasted longer in 2002. Somatic growth was significantly faster in 2001 $\left(0.4 \mathrm{~mm} \mathrm{~d}^{-1}\right)$ than $2002\left(0.3 \mathrm{~mm} \mathrm{~d}^{-1}\right)$. Larvae shared a common otolith growth trajectory both within and between year-classes, described by 3 different growth phases: an initial latency period followed by a period of accelerating growth before reaching an asymptote. Daily otolith growth of the 2001 year-class was significantly faster in the age ranges 21 to $50 \mathrm{~d}$ and 61 to $100 \mathrm{~d}$, with larvae having an average asymptotic growth of $2.1 \mu \mathrm{m} \mathrm{d}^{-1}$ in 2001 and $2.0 \mu \mathrm{m} \mathrm{d}^{-1}$ in 2002. Average daily otolith growth for calendar day increased from June to mid-July each year, decreased until early August, and then increased again. Average sea surface temperature on the capelin nursery ground increased from March to August, and was higher in 2001 than 2002. The decrease in growth during increasing ambient temperature indicates that other environmental factors have significant effects on seasonal growth. Survival rate of larvae from hatch until August was 3 times higher in 2001 when larvae grew faster. Faster growth and higher survival during the first 4 mo of the 2001 year-class did not carry over to higher absolute recruitment at maturity.
\end{abstract}

KEY WORDS: Capelin larvae - Mallotus villosus · Otolith microstructure · Daily growth Growth model $\cdot$ Seasonal effects $\cdot$ Temperature

\section{INTRODUCTION}

Capelin Mallotus villosus is a small semelparous pelagic species of schooling fish with a circumpolar distribution in the northern hemisphere and is a keystone species in the boreal food web of the North Atlantic (Bailey et al. 1977a, Vilhjalmsson 1994, Palsson 1997). There are several geographically separated stocks of capelin, including the Icelandic capelin stock, the Barents Sea stock, and the capelin stocks off Newfoundland and Labrador (Templeman 1948, Vilhjalmsson 1994). For the Icelandic capelin stock, predicting recruitment to the spawning stock at age 3 is an important consideration in the fisheries management process (Vilhjalmsson 1994, Gudmundsdottir \& Vilhjalmsson 2002), as the stock supports a commercial fishery with annual catches reaching 1 million t (Anonymous 2006).
The fishery is based mainly on the maturing year-class, allowing a renewal of the fishable stock every year (Gudmundsdottir \& Vilhjalmsson 2002). This stock has large annual fluctuations in recruitment even though it is managed to protect a spawning stock biomass of 400000 t (Gudmundsdottir \& Vilhjalmsson 2002).

In Icelandic waters, the majority of capelin spawn in the spring (March to May) of their third year of life. Most of the Icelandic capelin stock spawns in waters south of $66^{\circ} \mathrm{N}$, off the south and southwest coast of Iceland (Vilhjalmsson 1994; see Fig. 1). The larvae hatch after 20 to $25 \mathrm{~d}$, ranging in size from 5.0 to $7.2 \mathrm{~mm}$ (Fridgeirsson 1976). While the eggs are demersal, the larvae ascend to the surface layers after hatching and drift with the surface currents in a clockwise direction around the island. The traditional nursery ground of capelin larvae is over the shelf, north and northwest of 
Iceland, north of $65^{\circ} \mathrm{N}$ (Vilhjalmsson 1994; see Fig. 1). For Icelandic capelin, inter-annual differences in temperature can be large on the nursery ground but are known to be minimal on the spawning grounds (Anonymous 2005).

Theoretical and empirical studies link growth to survival in fish (Houde 1987, Anderson 1988, Pepin 1991). Growth during the larval stage can be critical to survival for later developmental stages and eventual yearclass strength at recruitment to the fishery. Growth and survival of larvae from the Icelandic capelin stock has never been investigated, and the age at which year-class strength is established is unknown (Vilhjalmsson 1994, 2002), while year-class strength of capelin in the Barents Sea and Newfoundland stocks is established during the first few months of life, prior to the first over-wintering period (Leggett et al. 1984, Gundersen \& Gjøsæeter 1998, Carscadden et al. 2000, Dalley et al. 2002). This is a preliminary study of when year-class strength of the Icelandic capelin stock is established. We measured growth of 2 year-classes of capelin larvae from hatch until August, and the effects of ambient temperature on average year-class growth were explored.

\section{MATERIALS AND METHODS}

Data collection and laboratory methods. Capelin larvae were collected over the continental shelf around Iceland from August 8 to September 3, 2001, and from August 7 to August 25, 2002, during the annual larval
Fridgeirsson 1976, Begg \& Marteinsdottir 2000). The survey followed a fixed route. However, in 2002, parts of some transects were not surveyed due to time constraints. When capelin larvae were present at a station, a sample of 50 larvae was frozen in a small plastic cup (approximately $150 \mathrm{ml}$ ) filled with seawater. In 2001, capelin larvae were collected at 88 out of 212 pelagic stations and at 50 out of 152 pelagic stations in 2002 . The average survey abundance of capelin larvae was 82 individuals per nautical mile in August 2001 and 26 individuals per nautical mile in August 2002 (Sveinbjornsson \& Hjorleifsson 2002). Capelin spawning stock biomass was estimated to be $450000 \mathrm{t}$ in 2001 and $475000 \mathrm{t}$ in 2002 (Anonymous 2006). The estimated absolute year-class size 0 at maturity, adding together fish maturing at 3 and 4 yr of age, was 61.7 billion fish for the 2001 year-class and 88.5 billion fish for the 2002 year-class (Anonymous 2006).

In the laboratory, frozen samples were thawed and standard length (SL) of the larvae measured to the nearest $0.1 \mathrm{~mm}$ with an Optimas ${ }^{\circledR}$ image analysis system connected to a dissecting microscope. Next, wet weight of individual larvae was measured to the nearest $0.01 \mathrm{~g}$ using an electronic analytical scale. In total, 4189 capelin larvae were measured from the 2001 year-class and 2387 larvae from the 2002 year-class. SL of larvae ranged from 19.6 to $64.0 \mathrm{~mm}$ in 2001 and from 11.8 to $62.5 \mathrm{~mm}$ in 2002 (Fig. 2a). All capelin in this study were considered larvae, as capelin have an extended larval stage with completion of metamorphosis at SL of 75 to $80 \mathrm{~mm}$ (Bailey et al. 1977b, Doyle et al. 2002). As no larvae in the size range 5.0 to $11.8 \mathrm{~mm}$ (i.e. 0-group) fish survey of the Icelandic Marine Research Institute (Sveinbjornsson \& Hjorleifsson 2001, 2002; Fig. 1). Larvae abundance was estimated by combining information from trawl sampling and acoustic data. For collection of acoustic data, a Simrad EK500 38 kHz transducer was used (Begg \& Marteinsdottir 2000). Acoustic echograms were used to identity changes in densities of larvae, and catch per unit effort was calculated by measuring the distance towed in the scattering layer and the number of larvae caught in the trawl (Vilhjalmsson \& Fridgeirsson 1976). Samples were collected with a Harstad pelagic trawl (18 by $18 \mathrm{~m}$ opening; 0.5 by $0.5 \mathrm{~cm}$ cod-end mesh) usually towed at a depth of 20 to $50 \mathrm{~m}$. Sampling was not conducted at fixed locations but occurred approximately every $40 \mathrm{~km}$ or when the echogram indicated changes in the abundance of acoustic targets (Vilhjalmsson \&

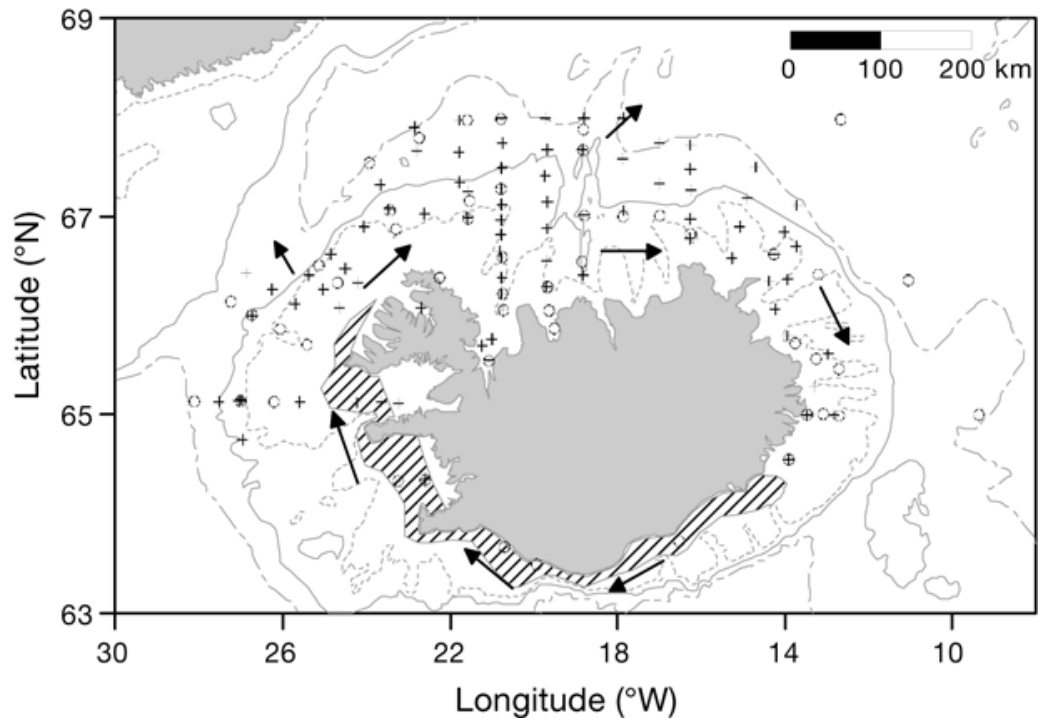

Fig. 1. Mallotus villosus. Sampling stations in 2001 (+) and 2002 (0). The hatched area is the main spawning ground and the predominant surface drift of eggs and larvae is shown by bold arrows (redrawn from Vilhjalmsson 1994).

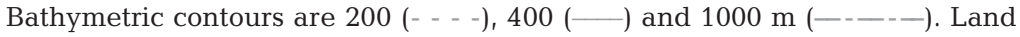
areas are shown as grey shaded regions 


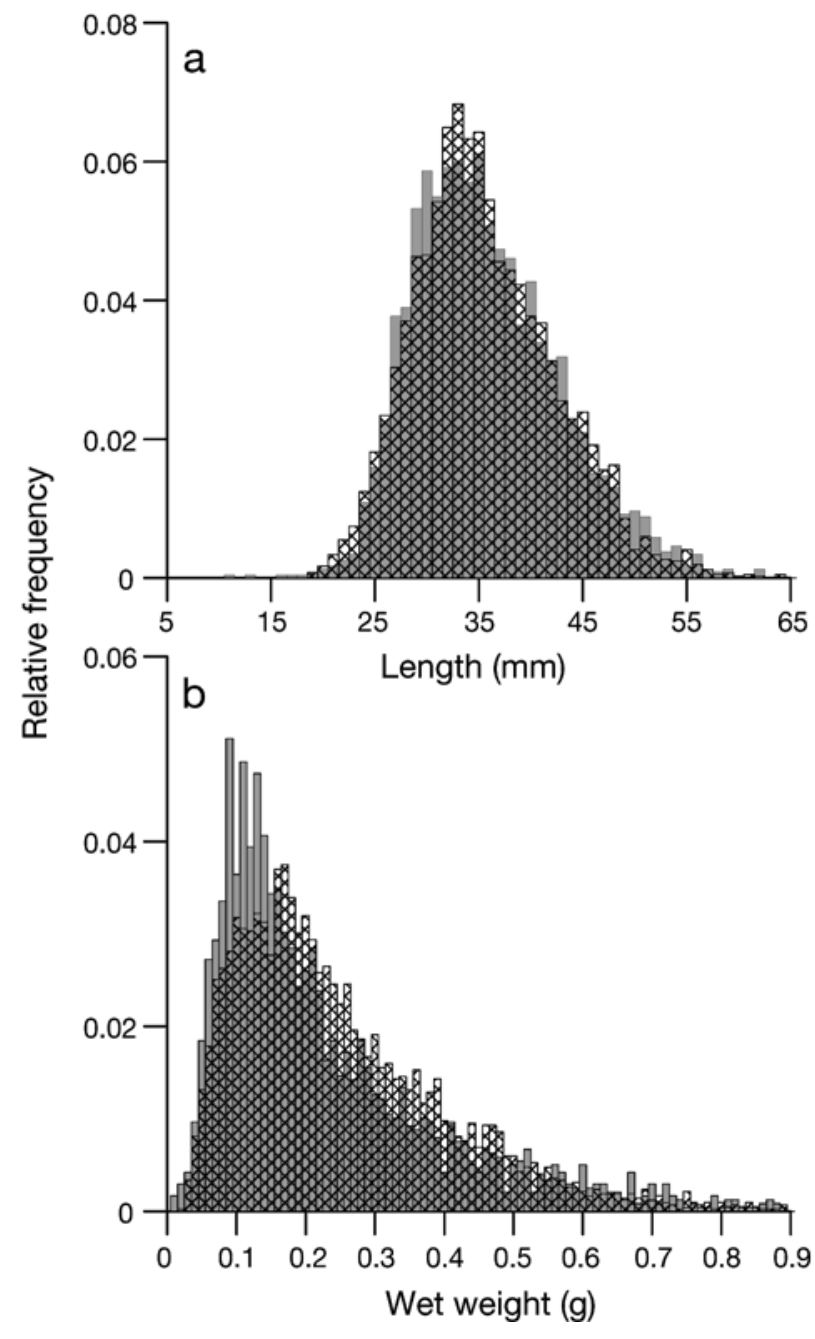

Fig. 2. Mallotus villosus. Relative frequency distribution, overlapping bars, of (a) standard length (mm) and (b) wet weight (g) for larvae in 2001 (cross-hatched bars, $\mathrm{n}=4189$ ) and 2002 (shaded bars, $\mathrm{n}=2387$ )

were caught, it was impossible to estimate growth of newly hatched larvae.

Daily otolith growth histories were reconstructed from larval otolith microstructure, as increment formation in capelin larvae shows daily periodicity (Gjøsæter \& Monstad 1985, Ivarjord et al. 2008). The sagittal otoliths were extracted from a random selection of 5 larvae per station. Stratified random sampling, where the size range of a sample was split into 5 equal SL intervals and 1 individual randomly picked from each interval, was used for selecting individuals. Extracted otoliths were mounted individually with a small drop of Crystal Bond ${ }^{\circledR}$ thermoplastic glue on microscope slides and sanded with 3.0 and $0.3 \mu \mathrm{m}$ lapping film. For otolith measurements, an Olympus BH-2 compound microscope, with $500 \times$ magnification, connected to an Optimas ${ }^{\circledR}$ image analysis system was used. Otoliths were extracted from 256 individuals in 2001 and from 216 in 2002 . Only 1 otolith was measured for each individual and the otolith with the clearest increments was used regardless of left or right. The number of increments was counted and the width of each increment was measured along the longest axis of the otolith. Otolith width, length, area and maximum radius were also measured.

Increment formation in capelin larvae is delayed as the first check is formed several days after hatching (Ivarjord et al. 2008). To our knowledge, the influence of temperature on larval age at first check formation has never been investigated in capelin. Due to limited knowledge, we assumed first check formation to be independent of temperature and to occur at the same age in all larvae. To emphasise that our age estimates are relative and not absolute, we use the phrase 'number of increments' instead of 'larval age'.

Thirty-one percent of the otoliths were measured again and there was no statistical difference in increment count between these repeated measurements (Paired $t$-test; $t_{2,146}=-0.37, \mathrm{p}=0.713$ ). The precision of repeated measurements was independent of age as the confidence interval (CI) for the regression of repeated measurements included 1 (0.98 CI: \pm 0.05 increment). Throughout the analyses, results from the first otolith measurement were used.

Statistical analysis. The average SL and average wet weight of all measured larvae $(\mathrm{n}=6576)$ was compared between year-classes using a $t$-test. The relationship between SL and wet weight of all measured larvae ( $\mathrm{n}=$ 6576) was investigated using linear regression on logtransformed data. Hatch dates of aged larvae $(n=472)$ were estimated by subtracting the number of increments from the capture date. The average hatch dates were compared between years using a $t$-test. The cumulative frequency distribution of hatch dates were also compared between years using a KolmogorovSmirnov goodness of fit test for continuous data (Zar 1999). Linear regressions (Zar 1999) were used to investigate if the relationship between otolith size and larval size changed with ontogeny. Otolith width, length, maximum radius and area were regressed on length of larvae using a pooled sample ( $\mathrm{n}=472$ ).

Growth was investigated using 2 different methods: somatic growth $\left(\mathrm{mm} \mathrm{d}^{-1}\right)$ and daily otolith growth $\left(\mu \mathrm{m} \mathrm{d}^{-1}\right)$. For comparison with other growth studies, somatic growth of larvae (SL range: 16.4 to $64.0 \mathrm{~mm}$ ), was inferred from otoliths using 'size-at- $x$ number of increments' of larvae and assuming daily increment formation from hatch. Otolith growth was analysed by analysis of covariance (ANCOVA) with year-class and number of increments, as explanatory variables. Partial correlation analysis of daily otolith growth, relative to age for both year-classes, showed high correlation in otolith growth 
over a range of $10 \mathrm{~d}$. Therefore, when comparing mean otolith growth trajectories, the age range, 0 to $110 \mathrm{~d}$, was split into 11 segments, each consisting of $10 \mathrm{~d}$.

Seasonal effects on individual growth trajectories were investigated by splitting each year-class into $10 \mathrm{~d}$ cohorts, based on hatch date, and calculating the average daily otolith growth for each cohort. Larvae that hatched on or before April 10 (Day 100) were merged into 1 cohort due to the low number of individuals. Larvae that hatched on or after June 20 (Day 171) were also merged into 1 cohort due to low numbers. Number of larvae in a cohort ranged from 10 to 48 individuals.

Two different growth models were fitted to average daily otolith growth. A logistic growth model (Brett 1979) was fitted to the data:

$$
W=W_{\infty}\{1+C[\exp (-G N)]\}^{-1}
$$

where $W$ is the average daily otolith growth $\left(\mu \mathrm{m} \mathrm{d}^{-1}\right)$, $W_{\infty}$ is the asymptotic average daily otolith growth $(\mu \mathrm{m}$ $\left.\mathrm{d}^{-1}\right), N$ is age (d), and $C$ and $G$ are parameters whose values were estimated. Secondly, a non-linear model with 3 parameters was fit to the data:

$$
W=A+\left\{\left[B\left(N^{D}\right)\right]\left(10000+N^{D}\right)^{-1}\right\}
$$

where $W$ is the average daily otolith growth $\left(\mu \mathrm{m} \mathrm{d}^{-1}\right)$, $N$ is age (d), and $A, B$ and $D$ are parameters whose values were estimated. A model with 4 parameters was tested, but as the confidence limits for the fourth parameter included zero, it was rejected.

All models, except the logistic and non-linear growth models, were based on a general linear model with normal error structure. Tolerance for Type I error was $\alpha=0.05$. If there was a significant difference in variance between year-classes, a non-parametric test was executed. Statistical analyses were done using SAS (SAS Institute 2001).

Sea surface temperature. Surface temperatures were assumed to be an appropriate proxy for temperatures experienced by larval capelin in the upper mixed layer. The upper mixed layer consists of the warm surface waters overlying the theromocline as a result of seasonal heating. Sea surface temperature (SST) data were obtained from in situ and satellite-based measurements for the waters surrounding Iceland $\left(61^{\circ}\right.$ to $69^{\circ} \mathrm{N}, 11^{\circ}$ to $28^{\circ} \mathrm{W}$ ) for the period 1990 to 2002 . The data were provided by the National Centre for Environmental Prediction (http://podaac-www.jpl.nasa.gov/ PRODUCTS/p119.html) for 1 degree grids on a weekly basis. During the 1990s, SST varied by area, with warmer waters south of Iceland and colder waters in the north. On average, August temperatures were 4 to $11^{\circ} \mathrm{C}$ north and south of Iceland, respectively. We divided the study area into waters north and south of $65^{\circ} \mathrm{N}$ latitude to calculate decadal monthly means for the period 1990 to 1999 , as well as monthly means for our 2 study years, 2001 and 2002. Seasonal ambient temperatures, which affect larval growth, were estimated as the summed integral for the period May to August each year. Temperature effects on year-class growth were investigated by calculating average daily otolith growth of year-class for each calendar day and comparing with seasonal changes in temperature. Effects of ontogeny were removed by excluding the first 40 increments in each otolith from average calculations.

\section{RESULTS}

The average length of all measured larvae was $36.1 \mathrm{~mm}$ for both year-classes, but the average wet weight of larvae was significantly greater in 2001 $(0.26 \mathrm{~g})$ than in $2002(0.24 \mathrm{~g})\left(F_{[1,6574]}=13.35, \mathrm{p}<0.001\right)$ (Fig. 2b). The linear relationship of log-transformed length and weight was described by the equations: log weight $=3.4$ log length $-5.9, R^{2}=0.95$ for the 2001 year-class, and log weight $=3.7$ log length $-6.5, R^{2}=$ 0.93 for the 2002 year-class. The length-weight relationships were significantly different between yearclasses as the interaction between year-class and weight was significant $\left(F_{[1,6572]}=124537.56, \mathrm{p}<0.001\right)$. Larvae smaller than $54.0 \mathrm{~mm}$ had greater average wet weight in 2001 but after larvae reached $54.0 \mathrm{~mm}$, the 2002 year-class had a greater average wet weight.

Estimated hatch dates occurred over a similar time span between years. In 2001, larval hatching started on March 1 and ended on June 28, with a mean hatch date of May 17 (Fig. 3). In 2002, hatching started on March 12 and ended on July 20, with a mean hatch date of May 22. The mean hatch dates were not significantly different between years $\left(F_{[1,470]}=3.12, \mathrm{p}=\right.$ $0.078)$, but the cumulative frequency distribution of hatch dates was significantly different $\left(D_{[472]}=0.14, \mathrm{p}=\right.$ $0.019)$. With the exception of one early hatching individual in 2001, hatching started earlier and lasted longer in 2002. The hatch times estimated in this study were within the known hatching season of Icelandic capelin of early March to July (Vilhjalmsson 1994).

The relationship between otolith size and larval length was significantly linear with no change in slope between small and large larvae (Fig. 4) for all 4 otolith variables measured. The relationship between otolith growth and somatic growth was proportional for capelin larvae in the size range 11.8 to $64.0 \mathrm{~mm}$.

\section{Growth}

Daily somatic growth was significantly greater $\left(F_{[1,468]}=41.02, \mathrm{p}<0.001\right)$ in $2001\left(0.4 \mathrm{~mm} \mathrm{~d}^{-1}\right)$ than $2002\left(0.3 \mathrm{~mm} \mathrm{~d}^{-1}\right)$ (Fig. 5). When the somatic growth 

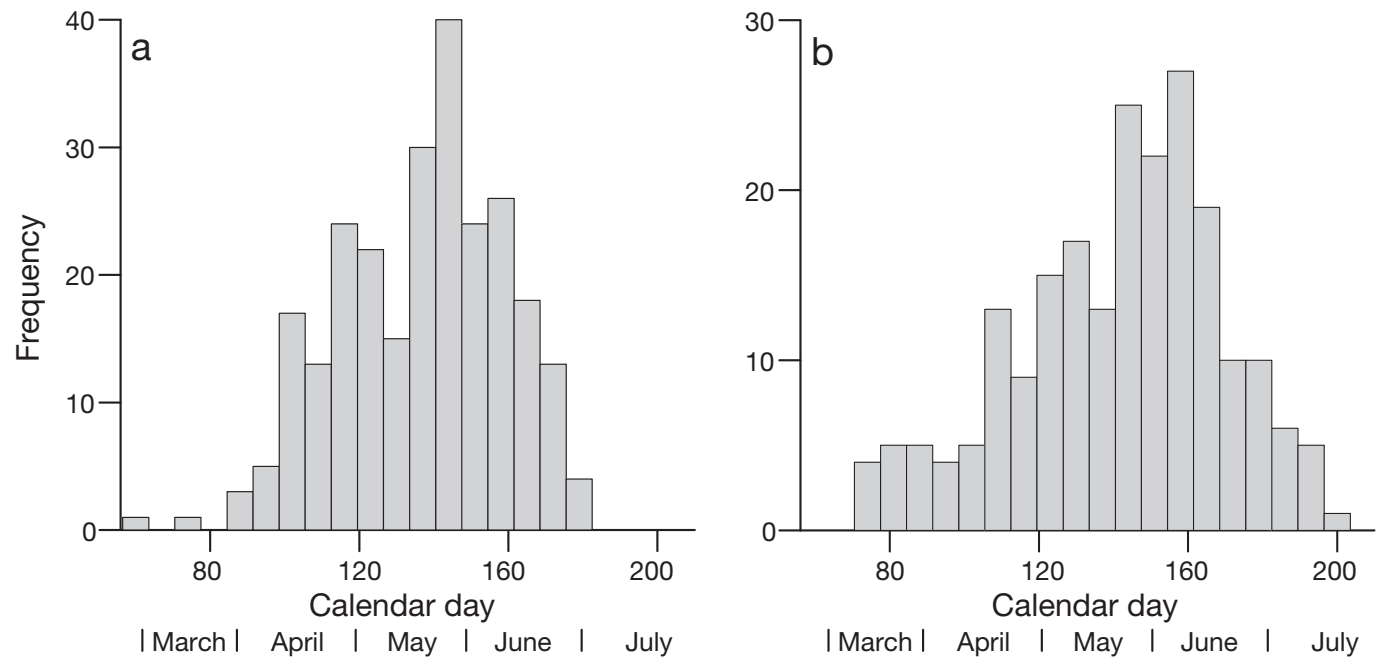

Fig. 3. Mallotus villosus. Frequency distributions of hatch dates, grouped into 7 d intervals, for (a) 2001 (n = 256 ) and (b) 2002 $(\mathrm{n}=216)$ year-classes. Hatch dates were back-calculated based on number of daily otolith growth increments formed after first check formation. No correction was made for delayed first check formation in larvae
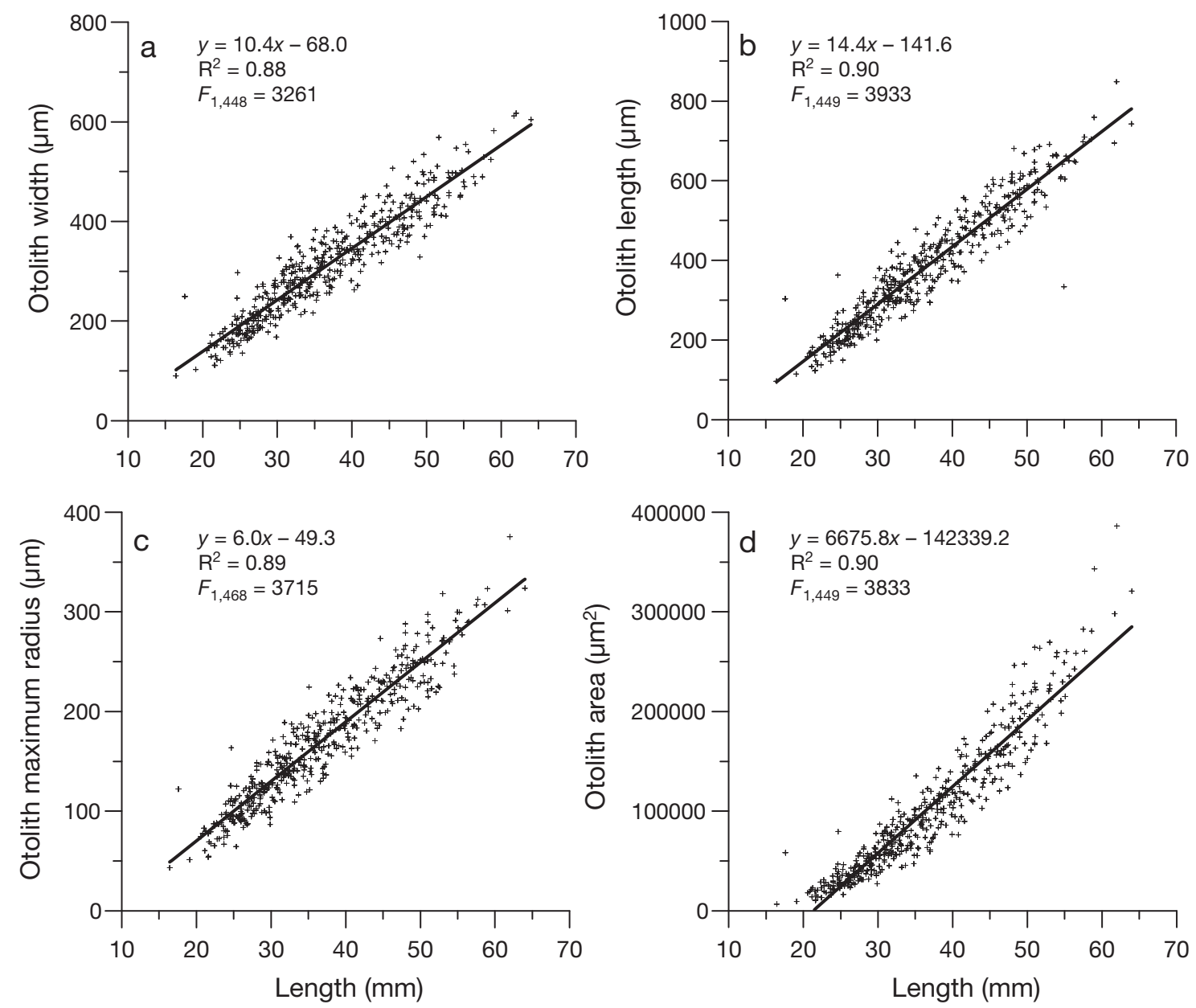

Fig. 4. Mallotus villosus. Larval growth and otolith growth for larvae in the 16.4 to $64.0 \mathrm{~mm}$ size range, where the relationship between larval length and otolith size is linear: (a) otolith width, (b) otolith length, (c) otolith maximum radius, (d) otolith area. Increments were counted in 472 larvae but otolith measurements were missing on a few occasions causing the lower degree of freedom. All regressions are significant at $\mathrm{p}<0.0001$ 
model was extended to the $y$-intercept (standard length of larvae at hatching), the estimated hatch size was $2.7 \mathrm{~mm}$ in 2001 and $10.7 \mathrm{~mm}$ in 2002, both of which are outside the published range of hatch size for Icelandic capelin larvae, 5.0 to $7.2 \mathrm{~mm}$ (Fridgeirsson 1976). One interpretation of this result is that the growth rate of capelin larvae is not linear from hatch to $16.4 \mathrm{~mm}$, the smallest larvae in the otolith study.

Annual average daily otolith growth increased with age of larvae, from 1.3 to $2.1 \mu \mathrm{m} \mathrm{d}^{-1}$ in 2001, and from 1.3 to $2.1 \mathrm{\mu m} \mathrm{d}^{-1}$ in 2002 (Fig. 6). Significant changes in annual average daily otolith growth occurred during the first $40 \mathrm{~d}$ of larval life, with growth decreasing for the first $10 \mathrm{~d}\left(F_{[9,462]}=2.95, \mathrm{p}=0.002\right)$, followed by a continuous acceleration in growth from age 10 to $40 \mathrm{~d}$ old (Days 11 to 20: $F_{[9,462]}=24.06, \mathrm{p}<0.001$; Days 21 to 30: $F_{[9,462]}=26.84$, $\mathrm{p}<0.001$; Days 31 to $\left.40: F_{[9,456]}=2.94, \mathrm{p}=0.002\right)$. For the age range of 51 to $60 \mathrm{~d}$, daily growth fluctuated significantly $\left(F_{[9,413]}=1.93, \mathrm{p}=0.046\right)$, but daily growth was not significantly different for the age ranges of 41 to $50 \mathrm{~d}$ and 61 to $110 \mathrm{~d}$. Daily otolith growth was not statistically different between year-classes for the first $20 \mathrm{~d}$ of life, but the 2001 year-class grew significantly more rapidly in the age ranges of 21 to $50 \mathrm{~d}$ and 61 to $100 \mathrm{~d}$ (Table 1). For the last $10 \mathrm{~d}$ of the age range studied there was no significant difference in otolith growth rates between years. Both year-classes followed a similar otolith growth trajectory as the interaction between year-class and otolith growth was not significant ( $p>0.05$ ).

Seasonal effects on daily growth of larvae were most pronounced at the asymptotic level (Fig. 6). Most cohorts followed similar growth trajectories, with an initial latent period, followed by an intermediate phase where growth accelerated, but all cohorts showed dif-

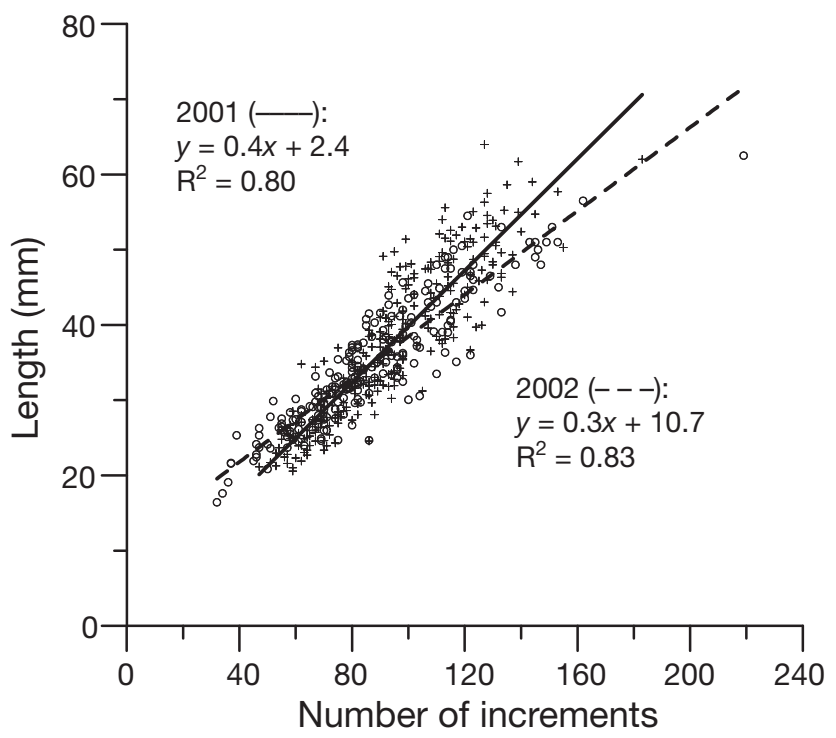

Fig. 5. Mallotus villosus. Somatic growth rate $\left(\mathrm{mm} \mathrm{d}^{-1}\right)$ of larvae in $2001(+, \mathrm{n}=256)$ and $2002(\mathrm{O}, \mathrm{n}=216)$ ferences when growth reached an asymptote. The only exceptions from the common growth trajectory were larvae hatching after calendar day 160 in 2001 as their growth trajectory lacked the acceleration phase seen in all other larval cohorts.

Results for the 2 year-classes and growth models (Eqs. 1 \& 2) are shown in Fig. 7, and parameters are listed in Table 2. For the logisitic growth model, only the asymptotic average daily otolith growth $\left(W_{\infty}\right)$ was significantly different between year-classes (2001, CI: $2.1 \pm 0.0 \mu \mathrm{m} \mathrm{d}^{-1} ; 2002$, CI: $2.0 \pm 0.0 \mu \mathrm{m} \mathrm{d}^{-1}$ ). The logistic model explains $99.8 \%$ of the variance for both years but did not model well the daily otolith growth at hatching and during the initial latency period. The non-linear model with 3 parameters had a better fit to the average daily otolith growth and captured the daily growth during the initial latency period (Fig. 7, Table 2). The non-linear model explained $99.9 \%$ of the variance for both year-classes and only the estimated value of parameter $B$ was significantly different between year-classes $\left(2001, C I\right.$ : $0.8 \pm 0.0 \mu \mathrm{m} \mathrm{d}^{-1}$; 2002, CI: $\left.0.7 \pm 0.0 \mu \mathrm{m} \mathrm{d}^{-1}\right)$.

\section{SST}

Seasonal SSTs during the 1990s were lowest in March and April at $1.9^{\circ} \mathrm{C}$, with waters warming rapidly from May, and reaching a maximum of $6.3^{\circ} \mathrm{C}$ in August (Fig. 8). In 2001, water temperatures were warmer than the 1990s throughout the year, with the exception of the month of June. In 2002, water temperatures were above and below the 1990s monthly average until July, after which temperatures remained above the long-term mean but lower than temperatures in 2001. The integral of temperatures for the May to

Table 1. Mallotus villosus. Statistical results for comparison of mean daily otolith growth between 2001 and 2002 yearclasses. The total age range is split into $10 \mathrm{~d}$ intervals based on auto-correlation in increment width. $\mathrm{N}$ is number of larvae included in the analysis

\begin{tabular}{|lcc|}
\hline Age range (d) & $\mathrm{N}$ & $\begin{array}{c}\text { Year-class } \\
\text { F-value (p-value) }\end{array}$ \\
\hline $1-10$ & 472 & $2.28(0.1321)$ \\
$11-20$ & 472 & $0.88(0.3492)$ \\
$21-30$ & 472 & $3.98(0.046)$ \\
$31-40$ & 466 & $4.63(0.032)$ \\
$41-50$ & 458 & $4.63(0.049)$ \\
$51-60$ & 423 & $1.58(0.210)$ \\
$61-70$ & 368 & $8.28(0.004)$ \\
$71-80$ & 306 & $8.92(0.003)$ \\
$81-90$ & 236 & $6.72(0.010)$ \\
$91-100$ & 156 & $6.33(0.013)$ \\
$101-110$ & 121 & $0.88(0.351)$ \\
\hline
\end{tabular}




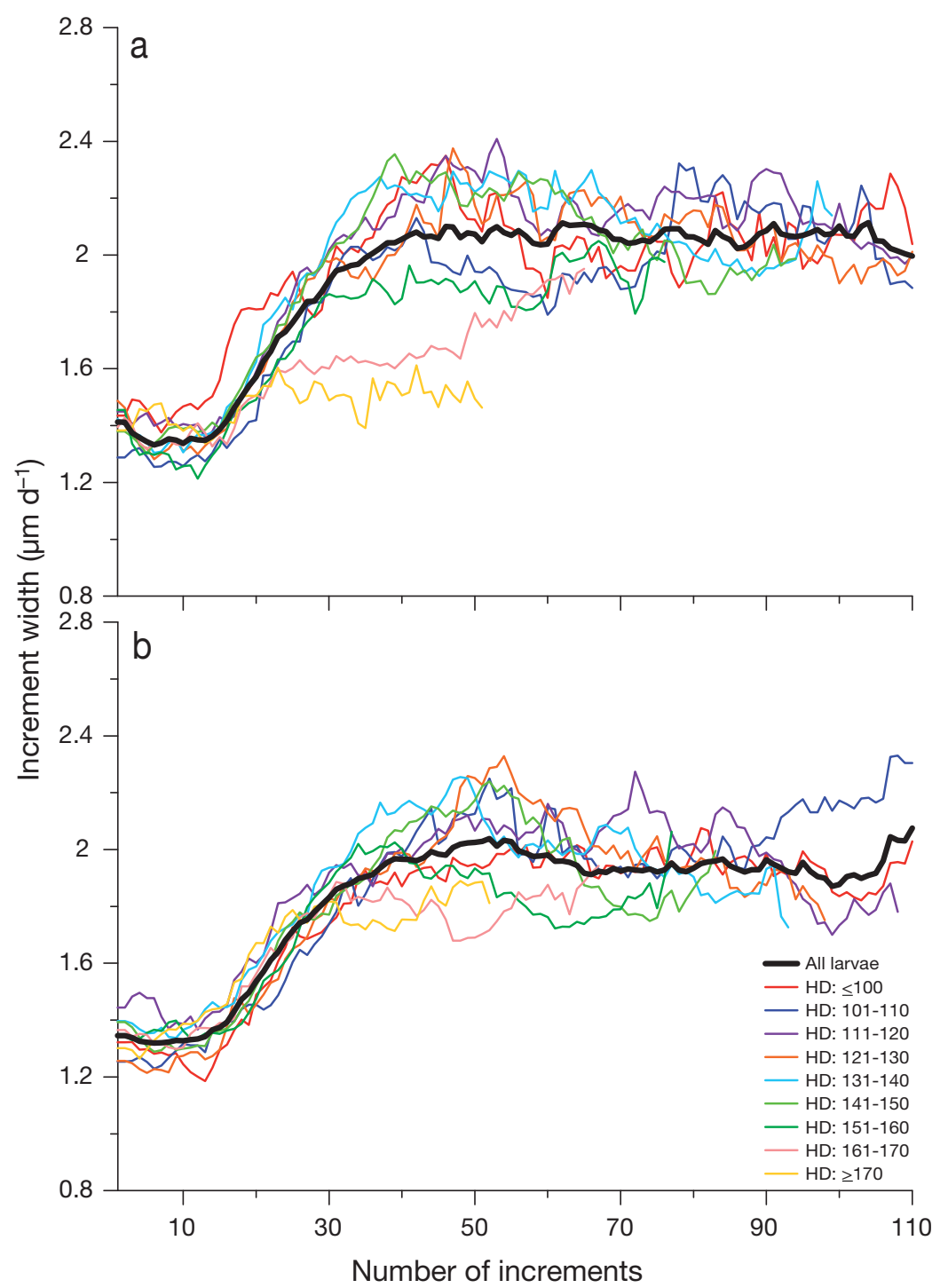

Fig. 6. Mallotus villosus. Average daily otolith growth $\left(\mu \mathrm{m} \mathrm{d}^{-1}\right)$ of larvae in (a) 2001 and (b) 2002. Each year-class was split into sub-classes based on hatch date with each class representing a $10 \mathrm{~d}$ interval. HD indicates hatch date (calendar day) for each sub-class. The heavy black line represents the average for all larvae in a given year-class

August period averaged $19.8^{\circ} \mathrm{C}$ in the $1990 \mathrm{~s}$, compared to $21.2^{\circ} \mathrm{C}$ in 2001 and $19.6^{\circ} \mathrm{C}$ in 2002 .

Average daily otolith growth during the asymptotic phase (first 40 increments in each otolith were eliminated from calculations) for calendar day fluctuated from 1.7 to $2.2 \mu \mathrm{m}$ (Fig. 9). The 2 year-classes shared a similar growth pattern with a phase of increasing growth in June into early July, followed by decreasing growth until early August when growth increased again. Growth in April to May was different between years as it decreased in 2001 but increased in 2002. Average monthly SST increased gradually from April to August, when is started to decline.

\section{DISCUSSION}

\section{Growth rates}

Somatic growth rates of capelin larvae measured in this study were similar to those of capelin larvae on the Grand Banks of Newfoundland at $0.35 \mathrm{~mm} \mathrm{~d}^{-1}$ (Frank \& Carscadden 1989), in the Gulf of St. Lawrence at 0.2 to $0.35 \mathrm{~mm} \mathrm{~d}^{-1}$ (Jacquaz et al. 1977) and in Barents Sea at $0.33 \mathrm{~mm} \mathrm{~d}^{-1}$ (Jakobsen et al. 2004). The growth rate of Icelandic capelin larvae ranges from 0.06 to $0.38 \mathrm{~mm} \mathrm{~d}^{-1}$, based on length frequency distributions measured from May to August (Magnusson 1966). Comparison with other studies shows that the growth of the 2001 yearclass was relatively high $\left(0.4 \mathrm{~mm} \mathrm{~d}^{-1}\right)$, while growth in 2002 was below average (0.3 $\left.\mathrm{mm} \mathrm{d}^{-1}\right)$. Biological conditions for larvae were better in 2001 based on weight-length comparisons. The higher growth rates and condition of larvae in 2001 implies that environmental conditions for feeding and growth were better in that year. Studies of growth of capelin larvae have shown that abundance of food has a significant influence on growth, with larvae growing faster when food is more abundant (Moksness 1982, Frank \& Leggett 1982, 1986).

\section{Growth model}

The growth trajectories for daily otolith growth of capelin larvae had 3 distinct phases. This pattern in growth rates was remarkably constant for most $10 \mathrm{~d}$ cohorts measured each year. The exceptions were the 2 youngest cohorts measured in 2001, larvae that would have hatched late in the season. A similar pattern was observed in growth of larval capelin from the Barents Sea reared in enclosures (Fig. 2 in Ivarjord et al. 2008). The consistency of the growth pattern suggests internal controls on growth are a function of their development and relatively independent of the environment.

Initially larval growth rates did not increase but remained relatively constant. This period lasted approximately $15 \mathrm{~d}$ as measured by number of otolith increments deposited from first check formation. On average, capelin do not deposit daily increments for $12 \mathrm{~d}$ after hatch (Ivarjord et al. 2008). Therefore, the 


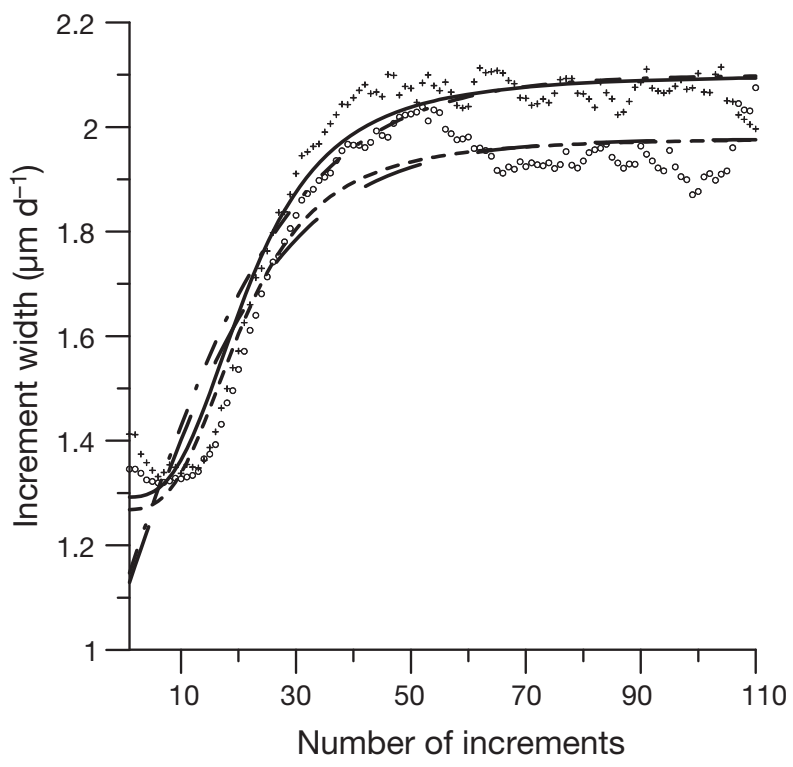

Fig. 7. Mallotus villosus. Average daily otolith growth of larvae in $2001(+, \mathrm{n}=256)$ and $2002(\mathrm{O}, \mathrm{n}=216)$. The data were fitted with a non-linear model (2001: solid line, 2002: dashed line) and a logistic model (2001: dashed-dotted line, 2002: long dashed line). See Table 2 for model parameters

initial period of latency in growth rates approximated a period of $27 \mathrm{~d}$. Yolk sac absorption following hatching occurs in 8 to $10 \mathrm{~d}$ (Fridgeirsson 1976) leaving a period of the order of $18 \mathrm{~d}$ during which we hypothesise that larvae were learning how to feed. The second growth phase was one of increasing growth rates that lasted approximately $20 \mathrm{~d}$ before they began to decelerate, approaching the maxima that were maintained over the remaining period sampled, on the order of $75 \mathrm{~d}$. Larvae were 22 to $24 \mathrm{~mm}$ in length when growth rates began to decelerate, which is approximately when metamorphosis begins with the onset of ossification (Doyle et al. 2002). Behavioural and physiological processes associated with development and ossification

Table 2. Mallotus villosus. Results for the daily otolith growth models (Eqs. 1 \& 2) for capelin larvae in 2001 and 2002. $W=$ average daily otolith growth $\left(\mu \mathrm{m} \mathrm{d}^{-1}\right)$, $W_{\infty}=$ asymptotic average daily otolith growth $\left(\mu \mathrm{m} \mathrm{d}^{-1}\right), N=$ age $(\mathrm{d})$ based on no. of otolith increments

\begin{tabular}{|lcccc|}
\hline \multirow{2}{*}{ Model } & \multirow{2}{*}{ Parameter } & Unit & \multicolumn{2}{c|}{ Value } \\
& & & 2001 & 2002 \\
\hline Logistic growth & & & & \\
$W=W_{\infty}\{1+C[\exp (-G N)]\}^{-1}$ & $W_{\infty}$ & $\mu \mathrm{m}$ & 2.1 & 2.0 \\
& $C$ & $\mu \mathrm{m}$ & 0.9 & 0.8 \\
& $G$ & $\mu \mathrm{m} \mathrm{d}^{-1}$ & 0.1 & 0.1 \\
Non-linear growth & & & & \\
$W=A+\left\{\left[B\left(N^{D}\right)\right]\left(10000+N^{D}\right)^{-1}\right\}$ & $A$ & - & 1.3 & 1.3 \\
& $B$ & - & 0.8 & 0.7 \\
& $D$ & - & 3.0 & 3.0 \\
\hline
\end{tabular}

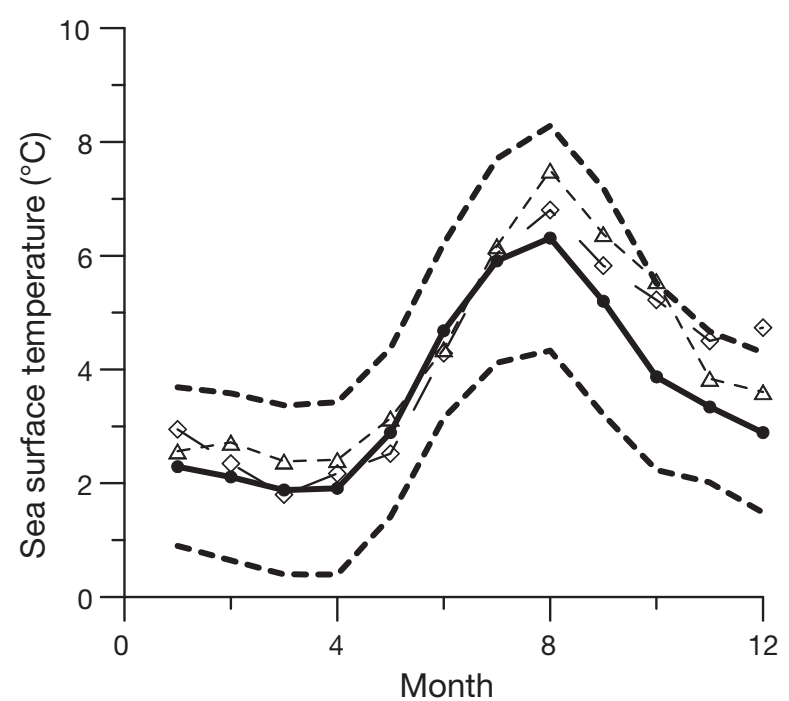

Fig. 8. Monthly average sea surface temperatures $\left({ }^{\circ} \mathrm{C}\right)$ for Icelandic waters, north of $65^{\circ} \mathrm{N}$ latitude, for the historical period 1990 to 1999 ( $\bullet$, heavy solid line, \pm SD heavy dashed line) and the study years $2001(\Delta$, dashed line) and $2002(\diamond$, long dashed line)

may coincide with the stabilisation of growth rates that we observed. Ossification in capelin is prolonged, not being complete until larvae are $60 \mathrm{~mm}$ in length (Doyle et al. 2002). This length equates to the oldest larvae measured in this study, 120 to 160 increments old.

Absolute age of larvae in this study was unknown as capelin larvae are known to delay first check formation (Ivarjord et al. 2008) but the variables controlling the delay process remain to be discovered. Research into first check formation in herring larvae (Folkvord et al. 2004) and cod larvae (Otterlei et al. 2002) indicate a strong influence of temperature, with increment formation starting at a later age in larvae experiencing lower temperatures. To our knowledge, no temperature validation study has been conducted for capelin larvae. The only information available for capelin larvae is an average delay of first check formation of 12 d for 389 larvae, with no range given (Ivarjord et al. 2008). Capelin age at first check formation is likely to be influenced by ambient temperature and, consequently, variable between individual larvae. As stated in 'Materials and methods', we assume first check formation to be independent of temperature and to occur at the same age in all larvae. This assumption is likely to be proven wrong by future research on temperature-dependent otolith growth of capelin larvae. If our assumption is wrong, bias was introduced into hatch 


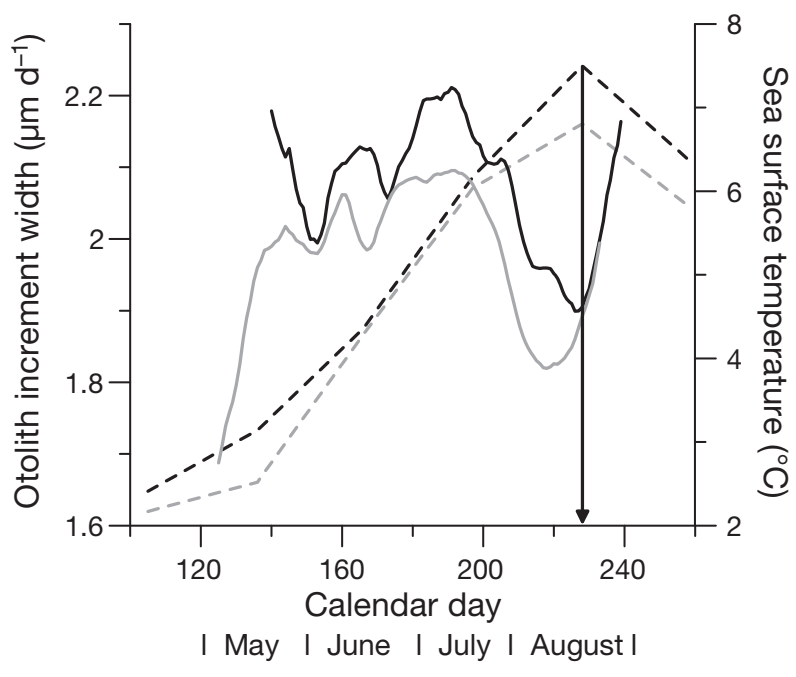

Fig. 9. Mallotus villosus. Average daily otolith growth (solid lines, $7 \mathrm{~d}$ running average) and monthly average of sea surface temperature (dashed lines) on the capelin nursery ground north of Iceland in 2001 (black) and 2002 (grey). Ontogeny effects were removed by excluding the first 40 increments from each otolith from average calculations. Calendar days with less than 10 larvae were excluded from the graph. The vertical line (solid, arrow) indicates the month of maximum temperatures

date distributions and growth rate calculations. To date, we have no means of estimating or correcting this possible bias.

\section{Growth and survival}

Capelin survival, standardised for spawning stock biomass, was approximately 3 times higher during the first 4 mo of life in 2001, when growth rates were higher. This is consistent with theoretical predictions (Werner \& Gilliam 1984, Anderson 1988) and empirical studies of fish larvae. Survival of Atlantic cod Gadus morhua larvae was higher for faster growing larvae (Campana 1996, Meekan \& Fortier 1996). Fortier \& Quinonez-Velazquez (1998) reported higher survival in faster growing pollock Pollachius virens larvae but not for haddock Melanogrammus aeglefinus. Atlantic mackerel Scomber scombrus larvae had higher survival in years of faster growth (Robert et al. 2007). There was no direct effect of capelin spawning stock size on larval abundance. The size of the spawning population was similar each year and, in fact, was 6\% higher in 2002. Mean hatch dates were not different between years, demonstrating that there was no seasonal difference in the larval growth periods. The higher growth and survival of capelin larvae in 2001 appeared to be a direct function of better environmental conditions for growth. Temperatures were warmer earlier in the season in 2001 than 2002 and were above the historical mean.
Higher growth rates equate to higher survival, a result of greater size-at-age within the larval stage and faster development through the larval stage (Houde 1987, Anderson 1988). We have no direct knowledge of potential differences in the larval prey in 2001 and 2002 with respect to timing and the magnitude of annual production or the species composition. Higher growth linked with higher temperature demonstrates that food (ratio) is not limiting (Brett 1979). Therefore, higher growth rates in 2001 when temperatures were higher imply that there was sufficient food available. Higher temperatures, and salinity, are related to an increased inflow of Atlantic water (Vilhjalmsson 2002). Previously, years with an increased flow of Atlantic water has been related to higher phytoplankton production (Gudmundsson 1998), higher zooplankton biomass (Astthorsson \& Gislason 1998) and greater weight of adult capelin (Vilhjalmsson 1994).

\section{Seasonal pattern-environment interaction}

Daily otolith growth in the asymptotic phase followed a similar seasonal pattern in both years, with the 2001 year-class having greater growth. There was no simple linear relationship between temperature and average growth as temperature increased continually from April to a peak in August, but growth fluctuated with a peak in the beginning of July prior to a sharp decline lasting to middle of August when growth increased again. Declining growth during a period of increasing temperature indicated the influence of additional environmental factors. The 2 year-classes had opposite otolith growth patterns in spring (April to May) with a sharp increase in 2002 but decline in 2001 with a moderate increase in temperature. This further supports the idea of otolith growth being influenced by more environmental factors than temperature alone. Decreasing growth during periods of increasing temperature implies limiting food availability (Brett 1979). With no data at all on food availability for capelin larvae in these 2 years, any discussion on the compounding effects of temperature and food availability on growth will remain mere speculation and outside the scope of this paper.

\section{Recruitment}

The relative abundances of the 2001 and 2002 yearclasses were not linked to recruitment to the spawning population at age 3, when the 2002 year-class was 1.4 times more abundant (Anonymous 2006). For Icelandic capelin, it has been hypothesised that year-class strength is not established until the second year of life, 
following the first over-wintering period (Vilhjalmsson 1994, 2002). In contrast, year-class strength of recruiting capelin in the Barents Sea and Newfoundland stocks is established during the first few months of life, prior to the first over-wintering period (Leggett et al. 1984, Gundersen \& Gjøsæter 1998, Carscadden et al. 2000, Dalley et al. 2002). It is not possible to draw broad conclusions about recruitment processes in the Icelandic capelin population based on the 2 years of observations in this study. It appears that Icelandic capelin differ from these other populations due to critical conditions that occur during their first winter. Future research on recruitment dynamics of Icelandic capelin should thus focus on their first winter survival.

Acknowledgements. We are grateful to the Marine Research Institute of Iceland for collecting capelin samples and providing logistical support. We thank Dr. H. Vilhjalmsson for the idea of conducting this study and his endless enthusiasm in answering our questions about everything regarding Icelandic capelin. AHO is indebted to her MS supervisor Dr. J. T. Anderson for his patience and commitment to teaching the craft of science. The draft for this manuscript was improved with comments from Dr. J. Carscadden and 3 anonymous reviewers. The work received financial support from the Memorial University of Newfoundland, the Icelandic Research Fund for Graduate Students, the Federation of Icelandic Fishing Vessel Owners, and the Icelandic Ministry of Fisheries.

\section{LITERATURE CITED}

Anderson JT (1988) A review of size dependent survival during pre-recruit stages of fishes in relation to recruitment. J Northwest Atl Fish Sci 8:55-66

Anonymous (2005) pættir úr vistfræði sjávar 2004. (Environmental conditions in Icelandic waters 2004.). Hafrannsóknastofnunin Fjölrit nr 116:1-54 (In Icelandic with English summary)

Anonymous (2006) Nytjastofnar sjávar 2005/2006. Aflahorfur fiskveiðiárið 2006/2007 (State of marine stocks in Icelandic waters 2005/2006. Prospects for the quota year 2006/2007.) Hafrannsóknastofnunin Fjölrit nr 126:1-194 (In Icelandic with English summary)

Astthorsson OS, Gislason A (1998) Environmental conditions, zooplankton, and capelin in the waters north of Iceland. ICES J Mar Sci 55:808-810

Bailey RFJ, Able KW, Leggett WC (1977a) Seasonal and vertical distribution and growth of juvenile and adult capelin (Mallotus villosus) in the St. Lawrence estuary and Western Gulf of St. Lawrence. J Fish Res Board Can 34: 2030-2040

Bailey RFJ, Able KW, Leggett WC (1977b) Evidence for the presence of a metamorphic check in capelin (Mallotus villosus) in otoliths and implication for age determination. J Fish Res Board Can 34:2008-2014

Begg GA, Marteinsdottir G (2000) Spawning origins of pelagic juvenile cod Gadus morhua inferred from spatially explicit age distributions: potential influences on yearclass strength and recruitment. Mar Ecol Prog Ser 202: 193-217

Brett JR (1979) Environmental factors and growth. In: Hoar WS, Randall DJ, Brett JR (eds) Bioenergetics and growth,
Vol 8. Academic Press, New York, p 599-667

Campana SE (1996) Year-class strength and growth rate in young Atlantic cod Gadus morhua. Mar Ecol Prog Ser 135: $21-26$

Carscadden E, Frank KT, Leggett WC (2000) Evaluation of an environmental-recruitment model for capelin (Mallotus villosus). ICES J Mar Sci 57:412-418

Dalley EL, Anderson JT, deYoung B (2002) Atmospheric forcing, larval drift, and recruitment of capelin (Mallotus villosus). ICES J Mar Sci 59:929-941

Doyle MJ, Busby MS, Duffy-Anderson JT, Picquelle SJ, Matarese AC (2002) Aspects of the early life history of capelin (Mallotus villosus) in the northwestern Gulf of Alaska: a historical perspective based on larval collections October 1977-March 1979. US Dep Comm NOAA Tech Memo NMFS-AFSC-132

Folkvord A, Johannessen A, Moksness E (2004) Temperaturedependent otolith growth in Norwegian spring-spawning herring (Clupea harengus L.) larvae. Sarsia 89:297-310

> Fortier L, Quiñonez-Velazquez C (1998) Dependence of survival on growth in larval pollock Pollachius virens and haddock Melanogrammus aeglefinus: a field study based on individual hatchdates. Mar Ecol Prog Ser 174:1-12

Frank KT, Carscadden JE (1989) Factors affecting recruitment variability of capelin (Mallotus villosus) in the Northwest Atlantic. J Cons Int Explor Mer 45:146-164

> Frank KT, Leggett WC (1982) Costal water mass replacement: Its effect on zooplankton dynamics and the predator-prey complex associated with larval capelin (Mallotus villosus). Can J Fish Aquat Sci 39:991-1003

> Frank KT, Leggett WC (1986) Effect of prey abundance and size on growth and survival of larval fish: an experimental study employing large volume enclosures. Mar Ecol Prog Ser 34:11-22

Fridgeirsson E (1976) Observation on spawning behaviour and embryonic development of the Icelandic capelin. Rit Fiskideildar 5:1-35

Gjøsæter J, Monstad T (1985) Primary growth rings in otoliths of Barents Sea capelin. Fiskdir Skr Ser Havunders 17: $521-528$

Gudmundsdottir A, Vilhjalmsson H (2002) Predicting total allowable catches for Icelandic capelin, 1978-2001. ICES J Mar Sci 59:1105-1115

Gudmundsson K (1998) Long-term variation in phytoplankton productivity during spring in Icelandic waters. ICES J Mar Sci 55:635-643

> Gundersen AC, Gjøsæter H (1998) A comparison between abundance estimates of the Barents Sea capelin (Mallotus villosus Müller) at the larval, 0-group and 1-group stage, for the year-classes 1981-1994. ICES J Mar Sci 55:95-101

Houde ED (1987) Fish early life dynamics and recruitment variability. Am Fish Soc Symp 2:17-29

Ivarjord T, Pedersen T, Moksness E (2008) Effects of growth rates on the otolith increments deposition rate in capelin larvae (Mallotus villosus). J Exp Mar Biol Ecol 358: 170-177

Jacquaz B, Able KW, Leggett WC (1977) Seasonal distribution, abundance and growth of larval capelin (Mallotus villosus) in the St. Lawrence Estuary and Northwestern Gulf of St. Lawrence. J Fish Res Board Can 34:2015-2029

Jakobsen RA, Pedersen T, Moksness E (2004) Growth rates and age distributions of capelin (Mallotus villosus) larvae in the Barents Sea investigated by otolith increment analysis. ICES CM/DD:08

> Leggett WC, Frank KT, Carscadden JE (1984) Meteorological and hydrographic regulation of year-class strength in capelin (Mallotus villosus). Can J Fish Aquat Sci 41: 1193-1201 
Magnusson J (1966) On capelin larvae (Mallotus villosus O. F. Müller) in Icelandic waters during the years 1960 to 1964. Rit Fiskideildar 4:1-34

Meekan MG, Fortier L (1996) Selection for fast growth during the larval life of Atlantic cod Gadus morhua on the Scotian shelf. Mar Ecol Prog Ser 137:25-37

Moksness E (1982) Food uptake, growth and survival of capelin larvae (Mallotus villosus Müller) in an outdoor constructed basin. Fisk Dir Skr Havunders 17:267-285

Otterlei E, Folkvord A, Nyhammer G (2002) Temperature dependent otolith growth of larval and early juvenile Atlantic cod (Gadus morhua). ICES J Mar Sci 59:401-410

Palsson OK (1997) Predator-prey interactions of demersal fish species and capelin (Mallotus villosus) in Icelandic waters. In: Proceedings of the International Symposium on the role of forage fishes in marine ecosystems, Anchorage, AK, November 13-16 1996. University of Alaska Sea Grant College Program Report No 97-01, Fairbanks, AK, p 105-126

Pepin P (1991) Effect of temperature and size on development, mortality and survival rates of the pelagic early life history stages of marine fish. Can J Fish Aquat Sci 48: 503-518

Robert D, Castonguay M, Fortier L (2007) Early growth and recruitment in atlantic mackerel Scomber scombrus: discriminating the effects of fast growth and selection for fast

Editorial responsibility: Hans Heinrich Janssen, Oldenburg/Luhe, Germany growth. Mar Ecol Prog Ser 337:209-219

SAS Institute (2001) The SAS system for Windows release 8.01. SAS Institute, Cary, NC

Sveinbjornsson S, Hjorleifsson E (2001) Report on the 0-group fish survey in Icelandic waters. August-September 2001. ICES CM/ACFM:20

Sveinbjornsson S, Hjorleifsson E (2002) Report on the 0-group fish survey in Icelandic waters in August 2002. ICES CM/ACFM:20

Templeman W (1948) The life history of capelin (Mallotus villosus O. F. Müller) in Newfoundland waters. Bull Nfld Gov Lab No 17:1-151

Vilhjalmsson H (1994) The Icelandic capelin stock. Capelin (Mallotus villosus Müller) in the Iceland-Greenland-Jan Mayen area. Rit Fiskideildar 13:1-281

> Vilhjalmsson H (2002) Capelin (Mallotus villosus Müller) in the Iceland-East Greenland-Jan Mayen ecosystem. ICES J Mar Sci 59:870-883

Vilhjalmsson H, Fridgeirsson E (1976) A review of 0-group surveys in the Iceland-East Greenland area in the years 1970-1975. ICES Coop Res Rep 54

- Werner EE, Gilliam JF (1984) The ontogenetic niche and species interactions in size-structure populations. Annu Rev Ecol Syst 15:393-425

Zar JH (1999) Biostatistical analysis, 4th edn. Prentice-Hall, Upper Saddle River, NJ

Submitted: September 10, 2008; Accepted: November 25, 2009 Proofs received from author(s): March 11, 2010 